\title{
Osvrti
}

https://doi.org/10.22210/suvlin.2021.091.08

\section{Osvrt na osvrt: 0 jezičnoj politici i objektivnosti}

\section{Ranko Matasović (2019), [recenzija knjige: Anđel Starčević, Mate Kapović \& Daliborka Sarić 2019, Jeziku je svejedno, Sandorf, Zagreb] Suvremena lingvistika 45/88: 279-284}

Ranko Matasovićje krajem 2019. u Suvremenoj lingvistici objavio kritički prikaz knjige Jeziku je svejedno (2019) [skraćeno: JjS]. Pritom je prihvatio neke od tvrdnjî iz knjige s kojima se preskriptivisti inače često, makar implicitno, ne slažu - npr. s time da varijacija u normi nije nešto loše, da hiperregulacija standardnog dijalekta vodi do disfunkcionalnosti, da znanost govori kako jest a ne kako treba biti (:280), da je norma konvencionalna, a ne rezultat svjesnog racionalnog odabira (: 283) itd. U ovom ću se odgovoru kritički osvrnuti na neke od drugih Matasovićevih teza iznesenih u njegovu prikazu. Smatram da je, unatoč skepsi prikazivača oko moguće debate, korisno razviti dijalog o problemima jezične politike, razjasniti neke od stajalištâ u JjS te ukazati na određene probleme u samom prikazu.

Matasović se na samom početku (: 280) slâžē da su autori knjige pokazali »do kakvih bezumnosti može doći ako se sve u standardnom jeziku želi propisati«, međutim odmah domeće da se postavlja "pitanje smislenosti prikupljanja svega budalastoga što je o standardnom jeziku napisano ili u medijima izrečeno, jer čitatelj ostaje uskraćen za one jezične savjete koji su njihovim korisnicima (svima koji konzumiraju jezične savjetnike ili daju svoje tekstove lektorirati) korisni - recimo tako što su im pomogli da se izraze jasnije i na način da budu razumljiviji većem krugu čitatelja ili slušatelja.« Nažalost, ovdje je riječ o neshvaćanju onoga čime se recenzirana knjiga bavi, kao i neshvaćanju kritike preskriptivizma kao pojave u cjelini (a ne samo pojedinih neuspjelih preskriptivističkih zahvata). Prikazivač pogrešno smatra »savjete« kritizirane $i$ analizirane $u$ knjizi najgorima $i$ »budalastima « u opoziciji prema nekim imaginarnim »dobrim« savjetima. Primjeri u Jeziku je svejedno (2019) niti jesu niti je mišljeno da budu izbor »najgorih savjeta - oni su naprosto izbor prosječnih savjeta, jedinih kakvi postoje. U knjizi, naravno, nisu mogli biti obuhvaćeni svi savjeti koji postoje, ali ona nikako ne obuhvaća samo »loše« savjete, dok bi tobože izostavljala one »dobre«. Autori knjige izrijekom kažu da »dobri savjeti« po definiciji ne postoje, niti mogu postojati (JjS: 191-193) te bi bilo korektno da je prikazivač to uvažio i, ako se s time ne slaže, obrazložio što bi po njemu »dobri savjeti« bili. Teoretski bi mogli postojati koliko-toliko suha objašnjenja što je standardno a što nije (tipa nosio bih je standardno, a nosio bi, nosil bi, nosio bim ili nosija 
bi nije), no takve savjete preskriptivisti u pravilu ne pišu - jer takve osnovne stvari govornici najčešće znaju (kod bih-bi-bi-bismo-biste-bi govornici znaju "griješiti« u standardnoj upotrebi jer je govorno bi za sva lica vrlo uvriježeno i nije ga se lako »riješiti« u upotrebi svjesnom samokontrolom svoje produkcije, ali rijetko tko će "pogriješiti« kod standardnog oblika nosio pokušava li ozbiljnije govoriti standardom) i jer su suhoparna objašnjavanja da se npr. piše potkrepa (ili potkrjepa ako se baš hoće), a ne potkrijepa u pravilu nezanimljiva za čitanje (osim toga, preskriptivisti najčešće ni nemaju dovoljno znanja da sinkronijski ili dijakronijski objasne zašto je potkrijepiti ali potkrepa te se njihova »objašnjenja « najčešće svode na nabrajanje preskriptivističkih neutemeljenih fetava). Stoga je preskriptivistička praksa jednostavno takva da je dotičnih »neutralnih « savjeta, koji bi se sveli na suho prepričavanje standardne gramatike ili pravopisa bez vrijednosnih sudova (koliko je to uopće moguće), razmjerno malo. Takvi su »savjeti«, uostalom, i nepotrebni jer za provjeru toga što je propisano kao standardno postoje pravopisi, gramatike i rječnici standardnog dijalekta. Pa se stoga u »savjetima « vrlo često uključuju neznanstvena, vrlo često bizarna, »objašnjenja« i upada se različite ideološke i znanstveno neutemeljene stavove. Neobično je, pritom, da Matasović žali što »čitatelj ostaje uskraćen « za te »dobre savjete«, ali pritom sâm ne navodi nijedan primjer »dobrog savjeta«. Također, iako će malo kasnije u tekstu sumnjati u ideologiju standardnog jezika, odmah sâm u nju upada tvrdeći da jezični »savjetnici«i lektori govornicima pomažu »da se izraze jasnije i (...) da budu razumljiviji većem krugu čitatelja ili slušatelja«. $\mathrm{Na}$ stranu činjenica da se i lektori i »savjetnici« u realnoj praksi bave dominantno progonom nasumično odabranih »loših « riječi, oblika i značenja, poistovjećivanje upotrebe standarda i jasnoće tj. razumljivosti (što prikazivač opet ponavlja i na sljedećoj stranici) nesumnjivo pripada ideologiji standardnog jezika. Naravno, nema apsolutno ništa loše u tome da se netko trudi da tekst bude što jasniji i razumljiviji (ako to autor želi - npr. neki pjesnici, književnici ili političari to katkad namjerno ne žele iako komuniciraju standardom, a jezik nam općenito omogućuje da, u skladu s potrebama i željama, budemo više, manje ili nimalo jasni), no to nije izravno povezano s time je li tekst na standardu ili na rigidnijem standardu. Matasović kao da nesvjesno i implicitno upada u tvrdnju da je standard »jasniji « od nestandarda iako je posve očito da to uopće nije nužno tako. Primjerice, lako se složiti da je standardno išao bih (koje može biti samo 1. lice jednine) u određenim kontekstima morfološki jasnije od nestandardnoga išao bi (koje može biti bilo koje lice u jednini), no isto tako je nestandardno riječko (čakavsko) bim-biš-bi morfološki razlikovnije ijasnije od standardnog (štokavskog) bih-bi-bijer čakavski razlikuje sva tri lica, a osim toga upotrebljava posebne kondicionalne oblike glagola biti umjesto da posuđuje aorisne (aorisni su oblici, doduše, naglašeni a standardni kondicionalni oblici nisu, no naglasak se u tekstovima ne piše). Dat ćemo još koji primjer. Recimo, rečenica pogrom kojeg je zaustavio, koja se po strožim kriterijima ne bi smatrala (potpuno) standardnom (zbog kojeg umjesto koji), nesumnjivo je u određenim kontekstima morfološki jasnija od strogo standardnog pogrom koji je zaustavio. Naime, prvaje re- 
čenica potpuno jasna (pogrom je objekt), dok je druga dvoznačna (pogrom može biti i subjekt i objekt). Ili, kajkavski (nestandardno) busa je pogodil, gdje je busa objekt, je morfološki jasnije i jednoznačnije od štokavskog (standardnog) bus je pogodio, gdje bus može biti i objekt i subjekt. Ukratko - nemoguće je inzistirati da je standardni dijalekt jasniji od nestandardnog jer to jednostavno nije u skladu s činjenicama. Kod jednih riječi i oblika je katkad jasniji (manje višeznačan) standardni dijalekt, a kod drugih neki nestandardni varijetet. Sama činjenica normiranja pojedinog varijeteta ne čini ga ni na koji način »jasnijim« (a od »veće jasnoće« je vrlo kratak put do toga da se standardni dijalekt proglasi i vrednijim od nestandardnih varijeteta). A ako bi se lektori ili nekakvi jezični priručnici teoretski i bavili pitanjem jasnoće izraza (što je daleko od realnosti u praksi), to nema izravne veze s tim što je u standardu što a ne šta ili vratâ a ne vratiju (dapače, vratiju je, opet, morfološki razlikovnije nego vratâ, premda je, strogo gledano, nestandardno) - pitanje jasnoće rečenice, koherencije teksta, razumljivosti i sl. je pitanje bez izravne veze s time na kojem se varijetetu taj tekst izriče. Recimo, nema sumnje da će svaki govornik hrvatskog savršeno razumjeti nestandardnu rečenicu poput šta si gledo?, štas gledo?, ča si gleda? ili kaj si gledal?, no vjerojatno velik broj govornikâ hrvatskog neće shvatiti izraz hegelijanska dijalektika kontingencije premda je taj izraz napisan na besprijekornu standardnom dijalektu. Sasvim je jasno da netko može biti (sadržajno i/ili retorički/stilski) potpuno nekoherentan i nejasan pišući ili govoreći na strogom standardnom dijalektu, kao što može biti i potpuno koherentan pišući ili govoreći na nekom nestandardnom dijalektu. Koliko će taj nestandardni varijetet biti široko razumljiv ovisi o društvenim okolnostima - npr. govor svih velikih gradova je u Hrvatskoj uglavnom općerazumljiv (uz manje iznimke - npr. neće svi van Dalmacije i priobalnih prostora znati što je kaciola, niti će svi Dalmatinci znati što je šeflja, ali to nije neka posebnost nestandarda jer isto tako neće svi znati ni što znači književna riječ zaimača).

Neobično je što se Matasović (: 281) čudi jednoj od osnovnih sociolingvističkih spoznaja, tj. »ideološkoj determiniranosti stavova o jezičnoj politici«i tvrdnji autorâ knjige da »neutralan pogled na jezična pitanja ne postoji«, tvrdeći da je ona »bez ikakvog dokaza ili empirijske potkrijepe«. Nije točno da autori knjige nisu dali nikakav dokaz ili potkrepu za nužnu ideologičnost bilo kakvog govora o jezičnoj politici - čitava knjiga o tome govori, a autori neprestano raskrinkavaju ideologičnost ne samo onih koje kritiziraju, nego i samih sebe i otvoreno priznaju (JjS: 13) da nisu i ne mogu biti neutralni, kao što nema neutralnosti ni u ekonomiji ili (nejezičnoj) politici. Ono na čemu se inzistira je to da ne-neutralni stavovi autorâ (kao što je onaj da standard treba služiti govornicima a ne obrnuto) jesu u skladu s objektivnim i znanstvenim spoznajama lingvistike o jeziku (npr. da se jezik uvijek mijenja, da je uvijek varijantan, da jezik ne postoji bez metaforike, da ne postoji i ne može postojati jezik u kojem svaka riječ ima samo jedno značenje itd.), dok su npr. preskriptivistički ne-neutralni stavovi vrlo često suprotni znanstvenim spoznajama o jeziku (npr. kada progone nasumične metafore ili tvrde da svaka riječ mora i može imati samo jedno značenje i sl.). Matasović opet, kao i tamo gdje govori 
o tobožnjim »dobrim jezičnim savjetima«, opet ne navodi niti jedan primjer nekakvog neutralnog stava o jezičnoj politici, što je nesumnjivo indikativno. Primjerice, prikazivačeva tvrdnja o normi »čija je naslijeđena tradicionalnost po sebi društvena vrijednost « (: 281) je apsolutno legitiman politički stav (kao što je legitiman i potpuno obrnut stav), no nesumnjivo je riječ o ideološkom tj. političkom stavu. Oni koji misle da je o jezičnoj politici moguće govoriti objektivno i neutralno morali bi primjerom pokazati kakve bi to tê neutralne i objektivne tvrdnje morale biti - the burden of proof je na njima jer oni koji misle da takvo što ne postoji samom logikom stvarî ne mogu dokazati da ono što ne postoji ne postoji (kao što se ne može dokazati ni nepostojanje nevidljivih patuljastih jednoroga - na onome je tko eventualno smatra da nevidljivi patuljasti jednorozi postoje da dokaže da postoje).

Dok je teško shvatiti kako bi stavovi (koji su po definiciji ne-neutralni jer su stavovi, tj. predstavljaju, rječnički rečeno, 'odnos prema komu ili prema čemu' tj. 'načelo kojeg se netko drži; uvjerenje, mišljenje'1) uopće mogli biti neutralni, moglo bi se pomisliti da bi lingvisti svejedno mogli neutralno pisati o jezičnoj politici tako da se, primjerice, opisujući jezičnu situaciju u nekoj zemlji strogo drže činjenicâ i pokušavaju suhoparno prenijeti što se ondje događa. Neki lingvisti u nekim situacijama doista pokušavaju tako pisati (iako se to nikako ne može primijeniti ni na što što o jezičnoj politici piše, primjerice, sâm Matasović), no ni u takvim slučajevima nema prave neutralnosti, premda se netko može truditi što je više moguće sagledavati više stranâ problemâ. Naime, neuplitanje u politiku je također politika - politika statusa quo. Nekritiziranje određene pojave i zadržavanje na "neutralnom« i »objektivnom « opisu neizravno daje legitimitet onome što se propustilo kritizirati. Neutralnost u pitanjima (jezične) politike ne postoji - izostanak eksplicitno verbalizirana stav je također svojevrstan stav. Primjerice, piše li neki sociolingvist o jezičnoj situaciji u Turskoj i nikako se kritički (makar retorički i izborom vokabulara) ne osvrne na zabranu Kurdima da govore svojim jezikom, to nije ni neutralnost ni objektivnost - to je neizravno davanje podrške statusu quo. Izostanak kritike i eksplicitnog stava (kakav god taj stav bio) ne znači da taj "grijeh nečinjenja« nije politički/ideološki - dapače, nereagiranje i zadržavanje na "pukom opisu «je možda još i političkije/ideološkije upravo zato što se gradi da je neidološko i objektivno, dok kritička reakcija bar često otvoreno priznaje da je ideološka te se tako pošteno odnosi prema svom polazištu2 ${ }^{2}$ Osim toga, ako bi se zastupao stav da je moguće biti neutralan kada se govori o jezičnoj politici, pa onda valjda i politici, dokle to ide? Trebaju li lingvisti biti »objektivni i neutralni« kada govore o tome kako su mali Aboridžini u Australiji i mali Indijanci u Kanadi dobivali batine u školi kad bi govo-

1 Definicije su prema Hrvatskom enciklopedijskom rječniku (Novi liber, Zagreb 2002), čiji je jedan od urednikâ sâm Matasović.

2 Smanjena količina ideologičnosti eventualno je moguća kada se govori o jezičnoj politici u davnoj prošlosti, primjerice u Hetitskom Kraljevstvu prije više tisuća godina, s obzirom da tu više nema nikakvih izravnih političkih uloga. No kako se povijest vrlo često koristi kao odmaknuti/preneseni način govora o sadašnjosti (pa tako i o budućnosti), naivno je misliti da prava neutralnost postoji čak i kada govorimo o (jezičnoj) politici u davnoj prošlosti. 
rili svojim jezicima? Ili, da zaoštrimo paralele i protegnemo ih van jezika, može li se i treba li biti »objektivan i neutralan« kad se govori recimo o genocidu. Holokaustu ili silovanjima?

Prikazivač nešto prije piše i da »mnogo toga u ovoj knjizi objektivnoga čitatelja mora ostaviti u nedoumici« (: 281), no nije eksplicirao o kojem se to »objektivnom čitatelju« radi. Neće biti da prikazivač misli ná se, s obzirom da je iz njegova prikaza očito da nastupa iz perspektive političkog i jezičnog konzervativizma i nacionalizma (a prikazivač, budimo pošteni, nï sām ne krije svoje političke nazore ni u svojim javnim nastupima, ni u svojim radovima o jezičnoj politici). To su, dakako, legitimni politički stavovi na koje pojedinci imaju puno pravo, no oni svakako nisu objektivni. Kako uopće biti objektivan oko bilo kojeg pitanja jezične politike, npr. oko standarda? Bilo kakvo mišljenje o standardu - pozitivno, negativno ili nešto između - nužno izriče neke vrijednosti i stavove o tome kako jezik u društvu mora izgledati. Bilo da se zalažemo za strogo hijerarhijski i elitistički standardni dijalekt ili za egalitaristički i demokratičan standard - to su nužno politički i ne-neutralni stavovi. Čak ni izbjegavanje rasprave o tim stvarima nije neutralno i objektivno jer i to, kako rekosmo, neizravno podržava status quo, koji nije ni neutralan ni objektivan. Objektivnosti nema čak ni u pitanjima oko kojih postoji širok konsenzus. Primjerice, čak i ako se svi složimo oko toga da je nekakva vrsta standardnog dijalekta potrebna u modernim društvima, kao što je potrebna i birokracija u nekom obliku, to ne znači da je to objektivan stav, da teoretski ne može postojati i moderno društvo bez standardnog dijalekta ili da netko nipošto ne smije imati i drugačiji stav. Da damo paralelu, to što ćemo se vjerojatno svi složiti da je robovlasništvo loše, a da žene moraju imati pravo glasa ne znači da je to objektivan i neutralan stav i da nije moguće i nešto drugo - npr. u Saudijskoj Arabiji žene nemaju pravo glasa, a u svijetu još uvijek postoje i prakse robovlasništva. To što će se većina ljudî danas složiti da je moralno apsolutno neprihvatljivo posjedovati druge ljude ne čini takav stav objektivnim i neutralnim - koliko god se mi slagali s njime, to ne znači da je to neutralan stav. To je itekako ideološki i ne-neutralan, ali danas uglavnom općeprihvaćen, stav (i dobro je da je općeprihvaćen). Jezična politika mora biti nekakva - pitanje je samo kakva i kome pogoduje. Minimalni preduvjet za suvislu raspravu je da se prizna da nema »objektivne politike« - dapače, politika je upravo najmanje objektivna kada fingira tobožnju objektivnost. Ideologija je najizraženija upravo kod onih koji misle ili hine da su iznad nje jer je u tom slučaju toliko pounutrena i normalizirana da izgleda kao da je nema.

Matasović zatim (: 281) govori da je ideologija standardnog jezika (što nije termin koji su izmislili autori, nego u sociolingvistici prilično poznat i prihvaćen naziv) »skup vrijednosnih stavova koji nisu logički povezani, tako da netko može prihvaćati jedne, a osporavati druge« te naširoko objašnjava da je sasvim moguće prihvaćati neke tvrdnje autorâ knjige, ali druge ne. No to uopće nije sporno. Pojedini stavovi i ideologemi unutar određene ideologije primarno nisu povezani »logički« nego politički/ideološki - oni doista tvore cjelinu i nadopunjavaju se, ali to ne 
znači da netko ne može prihvaćati samo dio tih stavova. Kao što je korištenje standardnog dijalekta uvijek personalizirano (JjS: 38), tako su i ideološki stavovi često personalizirani. Da bi opis određene ideologije kao cjeline (npr. konzervativizma ili socijalizma) funkcionirao i bio koherentan, uopće nije potrebno da svi koji se s dotičnim ideologijama identificiraju na ovaj ili onaj način slažu sa svim mogućim postavkama tih ideologija. Da nije tako, ne bi u pojedinim ideologijama postojali mnogobrojni različiti smjerovi (npr. na desnici klerikalizam, nacionalizam, monarhizam, libertarijanizam, minarhizam, islamizam, fašizam itd.), često i međusobno sukobljeni (npr. različiti nacionalizmi mogu biti međusobno sukobljeni) ili kombinirani na različite načine (npr. čovjek može biti i monarhist i klerikalist i nacionalist odjednom), dok su personalizirane individualne ideologije doslovce bezbrojne. Matasović tu zapravo samo naglašava nešto što je općepoznato i očito i nikako ne niječe ono što autori knjige govore. Pritom se služi i ne uvijek najsretnijim primjerima - Matasović (: 281) npr. kaže da netko može »istovremeno smatrati da [se] standardni jezik (...) ne treba prebrzo mijenjati, a ipak prihvaćati da su promjene nužne«. To je sasvim točno, no to uopće ne izlazi iz okvirâ uobičajene konzervativne političke ideologije jer će malo koji konzervativac misliti da je moguće doista u doslovnom smislu riječi očuvati status quo i da je svaka promjena loša - dapače, prihvaćat će neke promjene (sve dok nisu "prebrze«), a često će i sâm aktivno tražiti čak i vrlo velike promjene (sve dok su to promjene prema »boljoj prošlosti«, tradiciji ili »tradiciji« i sl.). Osim toga, implicira se da autori knjige da misle da se standardni dijalekt mora brzo i stalno mijenjati, što je stav koji autori naprosto nikad nisu iznijeli. Ni govorni se jezik najčešće ne mijenja nekom velikom brzinom pa nema nikakve realne potrebe ni da se službena varijanta jezika mijenja jako brzo. Matasović (: 282) nadalje tvrdi da »[p]romatranje standardnoga jezika kroz prizmu suprotstavljenih 'ideologija' zamagljuje sliku i otežava suočavanje s konkretnim problemima jezične politike u nekom društvu «. S takvim se pak stavom vrlo teško složiti - teško da raskrinkavanje realnopostojećih, ali često skrivenih, ideoloških polazišta »zamagljuje sliku«. Upravo suprotno, bez objašnjavanja ideologije u pozadini sliku je potpuno nemoguće shvatiti i bili bismo nužno osuđeni na iluzije o »objektivnosti«, koje nema i koja je nemoguća. Staro je i poznato pravilo, kako već istakosmo, da je ideologija najprisutnija upravo onda kada se tvrdi da je nema - a vrlo je slično i s tvrdnjama da je, čak i ako ih ima, bolje o njima ne govoriti. Takva Matasovićeva tvrdnja, osim što je empirijski netočna, također i je vrlo ideologična - suprotstavljanje raskrinkavanju ideoloških pozicija nesumnjivo ima ulogu čuvanja statusa quo (u slučaju jezika: preskriptivizma - unatoč tome što se i sâm prikazivač s autorima knjige slaže oko mnogih stavova o preskriptivizmu).

Prikazivač nadalje kaže da je "problem što autori ne nastoje svoje teze empirijski dokazati« i da "nemamo empirijskih podataka o tome koliko lektora i jezičnih savjetnika loše obavlja svoj posao (: 282). Doista je neobična tvrdnja da u knjizi od gotovo 400 strana, s bezbroj primjerâ iz različitih medija, nema empirije. Prikazivač kaže da "prikupljeni primjeri u knjizi ne predstavljaju statistiku, a lako je pro- 
naći primjere loše prakse za bilo koju djelatnost « (: 282), no to je promašena kritika jer je cilj knjige upravo dokazati da nije problem u »primjerima loše prakse« $\mathrm{i}$ »lošem obavljanju posla«, nego u samoj naravi dotične prakse i posla. Da to ilustriramo ekstremnom usporedbom - knjizi koja kritizira robovlasništvo kao takvo nema smisla prigovarati time da "nemamo empirijskih podataka o tome koliko robovlasnikâ loše obavlja svoj posao« - problem je u samom robovlasništvu, a ne u nekim »lošim robovlasnicima«ili »lošim robovlasničkim praksama«. Kako se u knjizi i eksplicitno naglašava (JjS: 215) »Iako se preskriptivistički pristup jeziku u ovoj knjizi kritizira na osnovi stvarnih primjera naših najistaknutijih preskriptivista, valja neprestano voditi računa o tome da problem nipošto nije u pojedinačnim primjerima i pojedinim osobama - problem je upravo u neznanstvenosti, neprihvatljivosti i štetnosti čitavog tog modela i opskurantističko-šarlatanskog pristupa jeziku.«Problem nije $\mathrm{u}$ »lošim lektorima « $\mathrm{i}$ »lošim savjetnicima « nego u samoj ideji lektorâ (kakvi oni u realnosti jesu) i »savjetnikâ« - problem je preskriptivizam, a ne »loši « preskriptivisti. Ako pak prikazivač misli da postoje »dobri savjeti« $\mathrm{i}$ »dobar preskriptivizam«, on bi morao to, kako već rekosmo, empirijski dokazati ili bar dati kakav primjer »dobrog savjeta «-što nije učinio. Ako se autore knjige hoće kritizirati, potrebnoje kritizirati njihove prave teze - tj. njihovu kritiku preskriptivizma i ideologije standardnog jezika, a ne govoriti o tome kako autori tobože kritiziraju samo »loše preskriptiviste«, što je metodološki nekorektno. Naravno, sasvim je moguće zamisliti drugačiji svijet u kojem bi se lektori bavili npr. isključivo pitanjem jasnoće i koherencije teksta (u tekstovima koji tome teže - dakle, ne nužno, primjerice, u književnosti) ili sadržajnim poboljšavanjem prijevodâ i sl., no to nije ono čime se većina lektorâ danas u pravilu bavi. I to nema puno veze s time kakve su namjere lektorâ - od lektorâ se danas, nažalost, upravo očekuje da križaju "nepoćudne« i »loše« riječi i oblike i da provode u praksi rigidne vizije standardnog dijalekta. Čak i ako sâm lektor to ne želi - u pravilu će od njega to očekivati njegov urednik, šef ili izdavač ili će biti pod pritiskom da to očekuju kad ih nadobudni čitaoci ili gledaoci kritiziraju jer je netko upotrijebio »nepravilnu« ili »nehrvatsku« riječ. Problem nije u pojedinim lektorima, nego u samoj ideji lekture kako ona danas u pravilu izgleda - i to je ono što knjiga jasno govori, a prikazivač ne shvaća ili ne prihvaća. Isto tako, problem nije u pojedinačnim »savjetnicima« i »savjetima«, nego u ideji »savjetodavstva« općenito. Ako pak postoje primjeri »dobrih savjeta«, čudno je, treba i treći put ponoviti, što prikazivač nije naveo makar jedan. A čak i kad bi se dali primjeri tih imaginarnih »dobrih savjeta« (kao što je moguće spomenuto suho navođenje toga što je službeno propisano, a što nije), to bi bilo potpuno besmisleno jer je realna praksa »savjetodavstva«(tj. savjetodavljenja, kako to naziva Ivo Pranjković) potpuna suprotnost suhoparnu prepričavanju pravopisa i standardne gramatike. Također, čisto načelno je problematično tvrditi da je nešto pogrešno jer se ne radi o statističkoj studiji teško da je Jeziku je svejedno jedino lingvističko djelo koje se ne zasniva na kvantitativnoj nego na kvalitativnoj analizi. U konačnici, i sâm prikazivač najčešće piše 
lingvističke knjige i članke u kojima se ne poziva na statistiku pa to ne znači da su mu radovi zato bezvrijedni.

Prikazivač nadalje prigovara (: 282) da »ne znamo ni u kojoj je mjeri istina da ta nesavjesna praksa ima loše posljedice, odnosno da kod govornika dovodi do 'shizoglosije' - nigdje nam se ne nude nikakve statistike zasnovane na objektivnom uzorkovanju«. Opet je riječ o kritici u kojoj se bez argumentacije relativiziraju ozbiljni problemi i tobože se traži statistika i »objektivno uzorkovanje« da bi se o nečemu moglo govoriti. Istom bi se logikom moglo tvrditi i da se ne može govoriti o "nacionalnom identitetu«, kao što to čini prikazivač, ne dokaže li se prije toga »na objektivnom uzorkovanju «što to točno jest i postoji li to uopće u Hrvatskoj. Ili da je nemoguće išta pisati o dijalektima u Hrvatskoj dok se ne ponude »statistike zasnovane na objektivnom uzorkovanju« koje bi dokazivale da se u Hrvatskoj uopće upotrebljavaju dijalekti. Pri tome je, dakako, zanimljivo da se takvi standardi i kriteriji traže od knjige koja ima, kako i prikazivač sâm priznaje, »opsežnu bibliografiju « i nebrojene empirijske potvrde unutar sebe, dok za preskriptivizam takvih kriterija nema - tamo se ne traži ni bibliografija ni reference ni argumentacija. Dapače, brani se neka imaginarna »dobra savjetodavna praksa « iako se ne daje ni jedan jedini primjer »dobra savjeta«, »dobra savjetnika« ili »dobra savjetodavca«. Knjiga Jeziku je svejedno nije nastala u vakuumu i ničim izazvana - ona je jasan odgovor na svakodnevnu realnu preskriptivističku praksu u Hrvatskoj. Teško je prihvatiti kritiku koja o takvoj preskriptivističkoj štetnoj praksi nije imala ništa za reći više desetljeća, ali zato argumentiranu kritiku takve prakse odbija tobože zbog nedostatka »empirije« i »statistike«. U svakom slučaju, takva kritika teško da može pretendirati na svoju objektivnost.

Također se smëćē s uma da kvalitativna kritika koja se pruža u knjizi uopće ne ovisi o nuđenju »statistike zasnovane na objektivnom uzorkovanju« - čak i kad bi 100\% govornikâ u Hrvatskoj smatralo da je jezična politika sjajna i da ne maltretira ljude nepotrebno (a sigurno nije tako), to ne znači da je kritika nemoguća i da je u krivu. Bi li npr. medicina trebala odustati od svoje pozicije o cijepljenju zato što velik broj ljudî danas smatra da je cijepljenje štetno? Treba li biologija odustati od teorije evolucije jer velik broj ljudî misli da ljudi »nisu nastali od majmunâ«? Ovisi li to što će astrofizičari misliti o okretanju Zemlje oko Sunca o javnom mišljenju o tome? Je li Galileo trebao naprosto prihvatiti da većina ljudî tada misli obrnuto od njega? Trebaju li sociolozi u Saudijskoj Arabiji prihvatiti da nema smisla govoriti o ženskim pravima jer ondje žene, po službenoj državnoj politici (koja zacijelo ima i bar solidnu podršku u javnom mišljenju), ne smiju izlaziti same na ulicu? Bi li bilo prihvatljivo da neki apologet robovlasništva u SAD-u u 19. stoljeću kritizira abolicionizam time što nema "statistike zasnovane na objektivnom uzorkovanju« o tome što robovi misle o robovlasništvu? Bi li robovlasništvo bilo u redu ako većina robova smatra da je to zdravorazumski sustav i da je utopijski zamišljati drugačiji? Ako većina ljudî negdje vjeruje u horoskop, gatanje iz kave i pljuvanje preko ramena ako vidi crnu mačku na ulici, treba li znanost to prihvatiti zdravo za gotovo i ne kri- 
tizirati? Ukratko, čaki da statistike pokažu da je $100 \%$ govornikâ u Hrvatskoj u potpunosti internaliziralo preskriptivističke, konzervativne i nacionalističke stavove o jeziku i da preskriptivistički zulum smatraju zdravorazumskim i posve opravdanim, sve to nije nikakva zapreka tome da lingvisti i jezični aktivisti prezentiraju javnosti svoje argumentirane stavove protiv toga. Jezična politika je, kako je već rečeno, politika. A politika nije stvar pukog opisa, prikaza i prihvaćanja postojećeg stanja, tj. mišljenjâ koja ljudi trenutno imaju - a ta mišljenja ne nastaju spontano ni u vakuumu, nego itekako ovise, sviđalo se to kome ili ne, o trenutnoj vladajućoj ideologiji, odnosu snagâ u društvu i realnim materijalnim interesima onih na poziciji moći. Sastavni dio svake politike jest i pokušaj da se politika i razmišljanje o njoj promijeni. Kako jednoč reče jedan slavni mislilac, parafraziramo, stvar nije samo $\mathrm{u}$ interpretaciji svijeta, poanta je u tome da ga izmijenimo. Utoliko autori knjige Jeziku je svejedno uopće ne bježe od toga da aktivno zagovaraju određeni smjer u jezičnoj politici i da jezičnu politiku žele mijenjati, kao i ono što ljudi o jeziku misle. I pritom smo, a što je i intelektualno i politički pošteno, vrlo otvoreni i jasni o svojoj vlastitoj političkoj poziciji i jasno razgraničavamo razlike između onoga što je lingvistika kao znanost objektivno spoznala o jeziku (a protiv čega nikada ne idemo) i naših političkih/ideoloških pozicija - za razliku od druge (preskriptivističke) pozicije koja glumi neutralnost i objektivnost i niječe vlastitu ideološku poziciju iako u većini slučajeva njezini politički stavovi ne samo da su štetni za većinu govornikâ, nego su i suprotni objektivnim i znanstvenim spoznajama o jeziku. Doista, bijedna bi ijadna bila lingvistika koja o svim problemima - pa i onima jezične politike - ne bi razmišljala sama, suštinski i kritički, nego bi pristajala uz (nimalo neutralni) status quo samo zato što takvo mišljenje možda trenutno prevladava u društvu.

Prikazivač dalje nastavlja (: 282) da »su autori nekritički na hrvatske prilike preslikali sociolingvističku situaciju iz anglosaksonskog svijeta, u kojem dijelu stanovništva dugo nije bilo omogućeno obrazovanje na standardnom jeziku (crncima u SAD, pripadnicima niže klase i imigrantima u Velikoj Britaniji), pa je opasnost da će netko zbog idioma kojim govori biti diskriminiran uistinu postojala, a donekle još uvijek postoji« te da u »Hrvatskoj, koja ima opće obrazovanje na jedinstvenom standarnom jeziku već više od stotinu godina, i gdje su sociolekatske razlike između privilegiranih i manje privilegiranih društvenih skupina mnogo manje izražene, takve opasnosti nema, a onda ni potrebe za aktivistima koji bi ispravljali navodne društvene nepravde vezane uz jezik. « U knjizi se razlika između Hrvatske i anglosaksonskih društava, kao i naše specifične okolnosti, više puta naglašava (JjS: 249-259, 62-63). To što se u Hrvatskoj obrazujemo »na jedinstvenom standarnom jeziku već više od stotinu godina «nije nikakva razlika od anglosaksonskih društava - i u SAD-u i Velikoj Britaniji se ljudi također više od stotinu godina obrazuju »na jedinstvenom standarnom jeziku«. To što su klasne razlike između našeg i anglosaksonskih društava manje nema veze s obrazovanjem na standardnom dijalektu nego s poviješću - u Britaniji npr. još postoji aristokracija, dok smo mi 45 godina imali radikalan realsocijalistički rez koji je narušio kapitalističku »normalnost«. To 
da nema "potrebe za aktivistima« u Hrvatskoj je samo prikazivačev subjektivan politički stav, koji je legitiman ali također i očito normativan, a ne deskriptivan s obzirom na brojne pozitivne reakcije čitalaca na knjigu i veliko zanimanje javnosti za nju. Osim toga, doista je teško glumiti da u Hrvatskoj nema preskriptivizma ili šizoglosije s obzirom da teško da ima bilo kojeg govornika, pa i lingvista, koji nikada nije bio ispravljan ili kritiziran zbog svoje jezične upotrebe, a bilo tko tko se bavi jezikom može potvrditi da je primio brojne upite o tome što je u jeziku "pravilno «. Prikazivač svakako ima pravo na svoj stav da su »društvene nepravde vezane uz jezik“ samo "navodne", no mora dopustiti i to da se s njim velik broj ljudi ne slaže.

Prikazivač zatim (: 382) negoduje što je "'aktivizam', prema autorima, samo lijevi (marksističko-egalitaristički) aktivizam, a nastojanja onih koji se brinu o standardnom jeziku samo su 'ugnjetavanje masa' (desni aktivizam, čini se, u tom svjetonazoru ne može postojati).« No lingvistički aktivizam (JjS: 58, 67-71) nije pojam koji su izmislili autori knjige - činjenica je naprosto da se u lingvistici taj pojam koristi upravo za progresivni, lijevi (ne nužno marksistički) aktivizam. Ono što prikazivač eufemistički naziva "nastojanj[ima] onih koji se brinu o standardnom jeziku« se u lingvističkoj praksi obično naziva preskriptivizmom. Nije točno da »desni aktivizam « ne može postojati - može, ali taj se termin zasad u lingvističkoj praksi ne koristi. Želi li ga prikazivač koristiti, morat će raditi na tome da ga popularizira. Autor ovoga osvrta se svakako može složiti da nije neopravdano govoriti o lijevom i desnom jezičnom aktivizmu, što, naravno, ne znači automatski da je ovaj drugi nešto pozitivno samo zato što smo ga drugačije nazvali. Pa ipak, neobično je kako prikazivač odjednom priznaje postojanje lijevih i desnih ideologija u jeziku iako je samo dva paragrafa prije (: 282) tvrdio da »[p]romatranje standardnoga jezika kroz prizmu suprotstavljenih 'ideologija' zamagljuje sliku i otežava suočavanje s konkretnim problemima jezične politike u nekom društvu«.

Prikazivač nadalje (: 282) imputira da »autori ne prihvaćaju«» »d]emokratsko pravo onih koji svjesno žele govoriti ili se pismeno izražavati tako da pokažu svoju obrazovanost, poštovanje hrvatske tradicije, ili čak pripadnost nekoj društvenoj skupini«. To je potpuno netočno. Autori knjige eksplicitno kažu (JjS: 376) da »[s] vatko ima pravo govoriti kako želi i tako odašiljati jezične i nejezične poruke koje želi te vidjeti kako će se drugi govornici prema tome odnositi.« Primjerice, prikazivač ima apsolutno pravo govoriti npr. hrvatskim Augusta Šenoe iz 19. stoljeća ako želi iskazati svoju privrženost hrvatskoj tradiciji. Isto tako, prikazivač ima pravo govoriti i latinski, želi li pokazati svoju obrazovanost. Kao što ima apsolutno pravo i pisati <ne ću > da bi time iskazao svoje političke stavove. Sve što autori knjige kritiziraju jest to što »se postojanje službene varijante jezika koristi kao platforma za promicanje štetnih i lingvistički potpuno neutemeljenih stavova o jeziku (a time i o društvu), pritom se lažno pozivajući upravo na znanost o jeziku« (JjS: 376). Naravno da svatko ima pravo u svojoj osobnoj jezičnoj upotrebi pridržavati se i najbesmislenijih uputa iz jezičnih »savjetnika« (kao što ima pravo govoriti i staroslavenski ili sindarinski ako mu se to mili), no nema ih pravo nasilno nameta- 
ti drugima pod krinkom tobožnje znanstvenosti. I, dakako, mora biti spreman na kritike lingvističkih aktivista, koliko god tko mislio da su oni nepotrebni. Nikako ne stoji da autori JjS zastupaju nekakvu nedemokratičnost i zabrane. Situacija je upravo suprotna - jezični konzervativci i preskriptivisti su ti koji bi drugima zabranjivali govoriti na neki način (npr. nestandardom u određenim situacijama) i koji bi drugima nametali kako moraju govoriti. Antipreskriptivisti se bore za nešto potpuno suprotno - upravo za to da svi imaju pravo izražavati se kako žele. Lingvistima uopće ne smeta što će neki preskriptivist govoriti i pisati svojim izmišljenim kvazistandardom - ono što lingvisti kritiziraju je nametanje takvog umjetnog i štetnog kvazistandarda drugima uz lažne i nadriznanstvene »argumente«. Svak ima pravo na svoje (subjektivne/ne-neutralne/političke/ideološke) stavove o svemu pa i o jeziku, no isto tako svak ima pravo kritizirati tuđe stavove smatra li da su oni štetni i imaju negativne posljedice - a pogotovo ima na to pravo ako se netko lažno poziva na znanstvenost kako bi opravdao svoje štetne stavove.

Prikazivač smatra "nedosljednim« (: 382) to što autori knjige koriste i naziv »standardni dijalekt« $\mathrm{i}$ »standardni varijetet«, no nije jasno na čemu se temelji ta kritika. U lingvistici postoje brojni termini koji se (djelomično) mogu preklapati npr. idiom, lekt, varijetet, varijanta itd. - i nije nikakva rijetkost da se i za potpuno isti pojam upotrebljava više naziva (pa će npr. netko jednom reći vokal, a drugi put samoglasnik). Uostalom, u hrvatskom i za samu znanost o jeziku postoje dva termina - lingvistika i jezikoslovlje (premda se oni upotrebno i konotacijski zapravo donekle i razlikuju). Doista je neobično postojanje različitih termina, koji se svi upotrebljavaju i koji katkada imaju i nešto različite konotacije ili označavaju gledanje iz različitih perspektiva, nazivati »nedosljednošću « i pritom još neutemeljeno aludirati na tobožnja neslaganja među pojedinim autorima iako nije uopće jasno što bi to trebalo dokazivati. Prikazivač nadalje tvrdi (: 282) da je termin standardni dijalekt "preuzet iz anglosaksonske tradicije, u suprotnosti s hrvatskom lingvističkom terminologijom i nepotrebno unosi zbrku«. U knjizi se (JjS: 10-112) otvoreno govori odakle je i zašto termin standardni dijalekt preuzet, a to da taj termin »nepotrebno unosi zbrku«je samo prikazivačev politički stav, na koji on svakako ima prava, ali koji je očito temeljen ne u nekakvim terminološkim brigama, nego u njegovu neslaganju s političkim stavovima autorâ knjige. Bilo bi neobično tvrditi da postoji nekakva objektivna, jednoobrazna i nepromjenjiva »hrvatska lingvistička terminologija" (kao da npr. autori knjige Jeziku je svejedno nisu lingvisti iz Hrvatske) u koju se ne mogu uvoditi novi termini da bi se i terminološki izrazile određene ideje - uostalom, i u anglofonoj je tradiciji standard language kao termin stariji od standard dialect. Osim toga, i sâm termin standarda potječe iz »anglosaksonske tradicije«, dok je tradicionalna lingvistička terminologija u Hrvatskoj baratala (a djelomično još uvijek i barata) terminom književni jezik (s tim da je zamjena tradicionalnog termina književni jezik pomodnijim standardnim jezikom imala daleko manje smisla nego namjerna upotreba termina standardni dijalekt). Čak i kad bi se inzistiralo da dijalekt kod nas može značiti isključivo ono što znači u kroatističkoj dijalektološkoj 
(!) terminologiji, tj. jedinica niža od narječja (što je pak jedinica niža odjezika), takav paralelizam ne bi stajao jer bi po toj logicistandardni jezik (kao tobožnji termin paralelan jeziku u dijalektološkom smislu) morao također imati svoja narječja i dijalekte, što nema puno smisla. Ukratko, ne postoji razlog zašto u hrvatskoj (sociolingvističkoj) terminologiji ne bi trebao postojati i termin standardni dijalekt - dapače, ako ćemo biti deskriptivni, a trebali bismo, taj termin sada ondje i postoji zahvaljujući, ako ništa drugo, knjizi Jezikuje svejedno, sviđalo se to nekome ili ne.

Prikazivač također imputira (:382-382) da premda, kako sâm priznaje, autori knjige izričito kažu »da nisu protiv standarda « u Zaključku »zapravo osporavaju potrebu za standardnim jezikom«. To nije točno. Autori nigdje ne izriču da su protiv postojanja standardnih dijalekata. No to što standardni dijalekti postoje ne znači da se zato govornici ili lingvisti moraju standardu klanjati ili nijekati stvarnost, npr. to da velik broj govornikâ vrlo rijetko ima potrebu govoriti standardom i da nije točno da bi se opća komunikacija i civilizacija raspale bez standarda. Tako, recimo, na primjeru govornikâ iz Bednje (JjS: 31-32) pokazujemo vrlo konkretno da, primjerice, kajkavci i van svoga mjesta komuniciraju na kajkavskoj koine bez upotrebe standarda. To se nekome može ne sviđati, ali to je naprosto činjenica. Isto tako, čakavac s Brača može u komunikaciji s nekim iz Slavonije upotrebljavati umjesto svog organskog bračkog urbani splitski štokavski umjesto strogoga standarda - pa će npr. svoje organsko ča si vidi(l)? zamijeniti splitskim šta si vidija? a ne nužno standardnim što si vidio? i svejedno će ga Osječanin razumjeti. Na lingvistici je da takve pojave opiše, a ne da se nad njima zgraža ili da opis realne jezične prakse automatski smatra "osporavanjem potrebe za standardnim jezikom«. Uostalom, to kako će u nekoj prilici razgovarati neki Bračanin i Osječanin ne znači da u novinama ili nekom zakonu neće pisati vidio (a ne vidi(ja), vidil i sl.), niti da postoji neko bogomdano pravilo kako bi Bračanin i Osječanin morali međusobno govoriti. Žele li oni komunicirati na standardnom dijalektu, to će i učiniti. Upravo je takva pretjerana osjetljivost što se tiče (ne)upotrebe standarda također dio ideologije standardnog jezika, oko koje je prikazivač tako skeptičan ${ }^{3}$.

Prikazivač se na kraju ljuti (: 283) što »je tradicija stavljena na istu razinu s 'osobnim preferencijama standardologa' « te se pita »[n]ije li tradicija ugrađena u standardni jezik te ju, ako to želi većina njegovih govornika, također valja poštovati pri normiranju?«, ipak pošteno dodajući da »tradicija nije univerzalna vrijednost, no ako većina govornika drži do nje i smatra je važnim činiocem nacionalnoga identiteta, kako je možemo zanemariti?«. Kao što sâm prikazivač priznaje, »tradicija nije univerzalna vrijednost « i pitanje tradicije u standardnom dijalektu je također pitanje ideološkog stava. Svakako da je i stav da je tradicija u standardu bitna također legitiman, kao i stav da tradicija nije ključna sastavnica standarda. Autori knjige sasvim sigurno nigdje nisu rekli da želje i stavove većine govornikâ treba zanemarivati - dapače, knjiga završava (JjS: 376) riječima da to »[k]akva će

3 Ako pak prikazivač doista misli da ideologija standardnog jezika ne postoji, šteta bi bila da takav stav ostane zakopan tek u jednoj recenziji na hrvatskom - bilo bi puno korisnije da ga autor objavi na engleskom. 
biti budućnost jezika i znanosti o jeziku u našem društvu u konačnici ovisi samo o nama«. Naravno, problem je u tome što govornici mogu imati različite stavove i što se ti stavovi mogu i mijenjati - i oni neće nužno uvijek biti stavovi koji će se svidjeti prikazivaču. Pri čemu prikazivač, da obrnemo kritiku koju je on plasirao o knjizi, ne nudi »nikakve statistike zasnovane na objektivnom uzorkovanju« koje bi dokazivale da većina ljudî u Hrvatskoj dijeli prikazivačeve stavove o tome da je »tradicija ugrađena u standardni jezik«i da je »važnim činiocem nacionalnoga identiteta«. Također treba istaći i to da autori knjige Jeziku je svejedno nigdje nužno ne zahtijevaju neke velike i revolucionarne promjene u standardu. Tradicija nije samo konzervativni ideologem, nego svakako i praktično pitanje - npr. ako su svi navikli da pišu svoja prezimena s <ć> (premda mnogi u svom fonološkom sistemu ne razlikuju /č/ i /ć/ kao foneme) ili ako se već skoro dva stoljeća u knjigama piše što (iako govornici u praksi upotrebljavaju i šta, ča, kaj itd.), svakako da to itekako može biti i vrlo praktičan argument protiv mijenjanja standardnog dijalekta u tom pogledu. Kako god bilo, autori se knjige Jeziku je svejedno, za razliku od, primjerice, onih koji su u 1990-ima predlagali uvođenje »korijenskog pravopisa« ili Ive Škarića, koji je kasnije htio radikalno mijenjati pravopis i standardni naglasni sistem ${ }^{4}$, uopće ne bave nekakvim prijedlozima pravopisnih, fonoloških, morfoloških, sintaktičkih ili drugih promjena u standardnom dijalektu. Sve za što se autori zalažu jest da se ne izmišlja proizvoljni kvazistandard (u kojem je npr. zabranjeno reći upaliti televizor) koji se protivi osnovnim lingvističkim spoznajama (npr. upotrebi metaforâ), kao i nasilnom nametanju tradicije i navodne »tradicije«. Naravno da svatko ima pravo upotrebljavati -oga i -og prema nekakvom izmišljenom pravilu, no nema pravo druge maltretirati svojim osobnim preferencijama i pravdati to tobožnjom "znanstvenošću«. Uostalom, i sama je knjiga Jeziku je svejedno napisana na standardnom dijalektu i sasvim je jasno i normalno da je na njemu napisana - bilo bi dosta neobično (iako teoretski moguće) da je napisana, primjerice, na dijalekatskom štokavskom ili govornom zagrebačkom. Standardni dijalekt kakvim je pisana tâ knjiga će nesumnjivo svatko prihvatiti kao standard - premda se u njemu ne poštuje ni jedna od preskriptivističkih izmišljotina koje autori kritiziraju. U knjizi se, dakako, poštuje ono što je općeprihvaćeno u praksi i što se već više od stoljeće î pō opisuje u gramatikama i rječnicima standardnoga dijalekta - npr. to da je standardni oblik što (a ne šta), da infinitivi završavaju na -ti (a ne $-t$ ) i da se fonem $h$ čuva (npr. kuhati a ne kuvati), no ne prihvaća se izmišljanje o upotrebi navezaka u pridjevskozamjeničkim nastavcima (tipa da se baš mora pisati dobroga starog prijatelja, a ne npr. dobrog starog, dobroga staroga ili dobrog staroga), ne prihvaća se da sobzirom da mora biti s obzirom na to da ili da glagol koristiti mora ići samo s instrumentalom, a ne is akuzativom. Dakle, sasvim je očito da standardni dijalekt koji zastupaju autori knjige Jeziku je svejedno nije ništa spektakularno novo, neviđeno i drugačije - to je jednostavno uobičajen oblik standardnog dijalekta koji većina govornikâ ionako u

4 Pritom se čak služeći netočnim podacima - usp. Kapović, Mate 2010, »O tobožnjoj neutralizaciji kratkih naglasaka u hrvatskom«, Croatica et Slavica Iadertina VI: 47-54. 
praksi upotrebljava. Utoliko je i pretjerivanje implicirati da autori knjige tobože zagovaraju nekakvo mijenjanje standarda »svakih nekoliko godina (: 283-284). Ono što se u knjizi kritizira nije nužno postojanje standardnog dijalekta kao takvo, nego nezdrav diskurs i odnos prema standardnom dijalektu i jeziku općenito, maltretiranje govornikâ izmišljenim i proizvoljnim "pravilima", mistifikacija standarda i proturanje često štetnih političkih stavova kao objektivnih i znanstvenih.

Također, ono što autori knjige naglašavaju jest standardni dijalekt kakav postoji nije inherentno i imanentno najbolji standardni dijalekt kakav može postojati, nije varijanta jezika koja je bolja, preciznija i logičnija od nestandardnih varijeteta. Naravno da bi standardni dijalekt mogao izgledati i drugačije i dakako da bi se mogao i promijeniti i da ne bi došlo do "propasti hrvatskog" pa čak ni do strašnih posljedica po hrvatsku naciju da se standard promijeni. Međutim, to ne znači da se autori nužno zalažu za nekakve promjene u pravopisu, fonologiji, morfologiji, sintaksi ili čak leksiku standardnoga dijalekta. Autorima je potpuno jasno da je pitanje toga što će biti u standardu u jednu ruku proizvoljno (što ne znači da nije ovisno o povijesnim, društvenim, političkim i drugim okolnostima) te stoga nema nužno previše smisla inzistirati da se jedna proizvoljnost zamijeni drugom. Npr. kada bi se danas standardno što će gledati? zamijenilo novim standardnim šta će gledat?, to ne bi promijenilo činjenicu da se u Zadru kaže što će gledati? ili da kajkavci, i neki drugi govornici (čakavci i štokavci), imaju »pune« infinitive. Naravno da se standard može mijenjati kad bi se to htjelo, no u JjS se to nigdje nužno niti traži niti predlaže (za razliku od npr. već spomenuta pokojnoga Ive Škarića koji je, recimo, predlagao ukidanje razlikovanja <č $\mathrm{i}$ <ć> u pravopisu ${ }^{5}$ ), niti je to poanta njihova djelovanja unutar jezične politike. Uostalom, pitanje nekakvih većih jezičnih promjena u standardnom dijalektu je pitanje o kojoj bi trebala demokratski raspravljati i odlučivati šira društvena i jezična zajednica, a ne nekolicina lingvistâ - bili ti lingvisti »jezični aktivisti« ili »vijeće za normu« u akademiji znanosti.

Prikazivač očito misli da se svi govornici hrvatskog nužno slažu s njim (što nije dokazao empirijski) i da će to uvijek biti tako te se unaprijed ne slaže s prigovorom da su neki današnji stavovi o jeziku možda "posljedica nacionalističke ideologije» (: 283), zdvajajući da »ako je sve u jezičnoj politici posljedica fiksnih ideologija koje zarobljavaju um svojih sljedbenika, teško da se u društvu o bilo čemu možemo dogovoriti«. Doista, sve u jezičnoj politici jest ideološko, no nije točno da su ideologije fiksne i nepromjenjive. To se vidi npr. po tome što prije 30-ak godina vjerojatno mnogim govornicima ideja da su hrvatski i srpski u osnovi isti jezik ne bi nimalo smetala, dapače vjerojatno bi im se činila zdravorazumskom, dok bi danas takva ideja mnogim govornicima u Hrvatskoj zacijelo bila prilično sporna. Što se tiče dogovora, on se svakako ne može zasnivati na pristajanju na neznanstveni preskriptivistički teror, nijekanju da preskriptivizam uopće postoji ili podmetanju očito ideoloških ideja kao objektivnih. Želimo li da se različiti stavovi nekako pokušaju

5 Usp. Kapović, Mate 2007, Hrvatski standard - evolucija ili revolucija? Problem hrvatskoga pravopisa i pravogovora, Jezikoslovlje 8.1: 6-76. 
pomiriti, potrebno je prvo biti načistac s tim kakvi ti stavovi jesu. A mnogi stavovi o jeziku stvarno jesu "posljedica nacionalističke ideologije « i, ako jesu, o tome treba i govoriti na takav način. To što su neki pojedinci emocionalno i identitetski investirani u nacionalističku ideologiju pa ne žele njezino propitivanje teško da može biti razlog da se lingvistika ili druge znanosti nacionalizmom ne bave. Nacionalistička ideologija svakako ne pada spontano s nebesa, ne nastaje ni slučajno ni bez ideoloških ciljeva, i teško da se možemo pretvarati da je tako samo zato što se tobože, budemo li o tome otvoreno govorili, »teško (...) u društvu o bilo čemu možemo dogovoriti«.

Prikazivač nadugo i naširoko (: 283-284) objašnjava da su jezik i standardni dijalekt bitni za pitanje identiteta, no nije jasno zašto to uopće čini s obzirom da je to jedno od osnovnih sociolingvističkih polazišta, koje autori knjige, potpuno je jasno, uopće ne niječu. No prihvaćanje očite činjenice, da standardni dijalekt (kao i drugi idiomi), može biti nosilac identiteta, ne znači da pritom stvaranje tog, primjerice nacionalnog (ili jedna varijante nacionalnog), identiteta ne može biti i štetno i toksično po samu govornu zajednicu. Ako se ljudi boje govoriti vlastitim jezikom i sami tvrde da ga ne znaju - nije li to problematično? Zašto bi bio problem to kritizirati i zašto bi kritika takve štetne jezične politike nužno ne bila »daleko od tvrdnje da on [standard] uopće nije potreban« (: 284)? Uostalom, zašto bi čak i tvrdnja da standard uopće nije potreban nužno bila tako šokantna i strašna? To je samo jedan mogući politički stav, koji je, kao i stav o važnosti »simbolično-identitetsk[e] funkcij[e] standardnoga jezika«, sasvim legitiman. Strah i od najmanje kritike jezične politike u vezi standarda je upravo pokazatelj kolikoje ideologija standardnogjezika strašno jaka, premda je prikazivač na više mjesta niječe ili trivijalizira. Također treba reći da identitet, pa i onaj temeljen na jeziku, ne mora nužno biti samo nacionalni (dapače, nacionalni identiteti su relativno mlada pojava) - identitet može biti i regionalni, gradski, kvartovski, antinacionalistički, internacionalistički itd.

Prikazivač se na kraju (: 284) pita »hoće li ova knjiga išta bitno promijeniti u društvu i njegovu stavu prema standardnom jeziku? « te kaže da je »mišljenje (...) ovoga recenzenta da ne će, već će zbog svojeg dogmatskog inzistiranja na ideološkoj naravi debate o problemima standardnoga jezika samo povećati konflikte, kojih u hrvatskom javnom prostoru ionako ne nedostaje. "Teško je izbjeći dojam da prikazivač svojim mišljenjem govori više o svojim željama u skladu sa svojim političkim stavovima, a manje o realnoj recepciji knjige Jeziku je svejedno. Potpuno je jasno da su sve društvene promjene obično spore i ne događaju se preko noći te u vezi toga ne treba imati iluzijâ, no određeni početni utjecaj je knjiga nesumnjivo već izvršila. On se vidi ne samo prema recepciji u javnosti i odjecima u medijima, nego, primjerice, i po tome što je prikazivač uopće napisao o njoj recenziju (što je recenzentu zacijelo prvi prikaz neke knjige o jezičnoj politici), kao i to što se u javnosti najavljuje osnivanje vijeća za normu u HAZU-u. Što se tiče denuncijacije »o dogmatsko[m] inzistiranj[u] na ideološkoj naravi debate o problemima standardnoga jezika«, nije baš jasno kako je to problem kad je i sâm prikazivač u svom prikazu nedvojbeno 
ogolio - priznavao to ili ne - svoja politička polazišta, primjerice otvoreno govoreći o »desnom aktivizmu« i zastupajući konzervativne političke stavove kroz cijeli tekst, premda, a što je pohvalno, na način da nije pritom (kao mnogi preskriptivisti) nijekao neke osnovne znanstvene spoznaje o jeziku (npr. da se jezik nužno mijenja, da je varijantan, da je metaforičnost neizostavan dio jezika itd.). Što se tiče "povećavanja konflikta «, konflikt je i dosad itekako postojao, ali dosad je samo jedna strana udarala, a druga tek sad polako diže glavu. Potpuno je jasno da bi pristalice rigidna pogleda na standardni dijalekt i politiku općenito zacijelo više voljeli da rasprava uopće nije pokrenuta, no vremena kad su preskriptivizam i ideologija standardnog jezika neometano vladala ovim prostorima su gotova. Dolazi nova generacija i stručnjakâ i laikâ koji na jezik gledaju drugačije i koji neće šutke pristajati na vladavinu preskriptivizma te dominaciju neznanstvenog $\mathrm{i}$ štetnog diskursa o lingvistici $\mathrm{i}$ jeziku u javnoj sferi.

Prikazivač u zadnjoj rečenici (:384) primjećuje da kritika preskriptivistâ, jezičnih konzervativaca i preskriptivizma neće dovesti do promjene njihovih stavova ili "navesti šutljivu većinu da prihvati vaše«. No knjiga Jeziku je svejedno uopće nema namjere mijenjati stavove aktivnih $i$ angažiranih preskriptivista koje kritizira, niti misli da će oni mijenjati svoje stavove. Ako netko na preskriptivizmu zarađuje, ako na njemu bazira svoj čitav habitus pa čak i napredovanje na fakultetu, teško da će mijenjati svoje stavove. Naša knjiga uopće nije namijenjena preskriptivistima i konzervativcima, niti namjerava mijenjati njihovo mišljenje - ona je namijenjena ponajprije običnim govornicima koji su žrtve njihove štetne i nazadne jezične politike, lingvistima koji se s takvom politikom u principu ne slažu, ali se sami bave drugim stvarima, te novoj generaciji lingvistâ koja će se, nadajmo se, odmaći od parohijalnosti, provincijalnosti i nezdravih ideja koje su dosad prožimale i struku i opću javnost. U tom svjetlu, autor ovog teksta se nada da će preskriptivizam kroz nekoliko desetljeća biti izgnan bar iz akademskih ustanova, kao što je to već slučaj npr. u anglosaksonskim zemljama. Bitka u široj javnosti će, dakako, biti puno duža i dugotrajnija, od čega autori knjige ne bježe, niti ona u konačnici može biti izborena samo u jeziku (JjS: 372). Oni kojima je stalo do nacionalnog identiteta utjehu će možda moći naći u tome da bi Hrvatska, dogodi li se bar dio promjenâ u odnosu prema jeziku za koje se autori knjige zalažu, mogla imati moderniji i znanstveniji pristup jeziku i jezičnoj politici od onoga koji prevladava u većini svijeta.

Mate Kapović 